\title{
Evaluation of PCR and multiplex PCR in relation to nested PCR for diagnosing Theileria equi ${ }^{1}$
}

\author{
Danielle C. Leal ${ }^{2}$, Cláudio R. Madruga ${ }^{2}$, Paulo F. de Matos², Bárbara M. P. da S. Souza ${ }^{2}$ \\ and Carlos R. Franke ${ }^{2 *}$
}

\begin{abstract}
Leal D.C., Madruga C.R., Matos P.F., Souza B.M.P.S. \& Franke C.R. 2011. Evaluation of PCR and multiplex PCR in relation to nested PCR for diagnosing Theileria equi. Pesquisa Veterinária Brasileira 31(7):575-578. Departamento de Produção Animal, Escola de Medicina Veterinária, Universidade Federal da Bahia, Av. Adhemar de Barros 500, Ondina, Salvador, BA 40110170, Brazil. E-mail: franke@ufba.br

Conventional PCR (PCRTeq) for diagnosing Theileria equi and multiplex PCR (M/PCRTeqBc) for diagnosing T. equi and Babesia caballi were comparatively evaluated with nested PCR (N/PCR-Teq) for diagnosing equine piroplasmosis. In DNA sensitivity determinations, in multiple dilutions of equine blood that had tested positive for T. equi, PCR-Teq and N/PCRTeq detected hemoparasite DNA in the larger dilutions (1:128), but did not differ significantly from the M/PCRTeq-Bc (1:64). In analyses on equine serum tested by ELISA, there was high agreement between this serological test and PCR-Teq $(k=0.780)$ and moderate agreement with $N /$ PCR-Teq $(k=0.562)$ and M/PCRTeq-Bc $(k=0.488)$. PCR-Teq found a higher frequency of $T$. equi both in extensively and intensively reared horses, but this was not significant in relation to $N /$ PCR-Teq $(\mathrm{P}>0.05)$, and both PCRs indicated that there was an endemic situation regarding T. equi in the population of horses of this sample. PCR-Teq was only significantly different from M/PCR-Teq-Bc $(\mathrm{P}<0.05)$. PCR-Teq presented high sensitivity and specificity, comparable to $N /$ PCR-Teq, but with the advantage of higher speed in obtaining results and lower costs and risks of laboratory contamination. This accredits PCR-Teq for epidemiological studies and for determinations on affected horses.
\end{abstract}

INDEX TERMS: Theileria equi, PCR, multiplex PCR, horses.

RESUMO.- [Avaliação da PCR e PCR multiplex com relação a nested PCR no diagnóstico de Theileria equi.] Uma PCR convencional (PCRTeq) para diagnóstico de Theileria equi e PCR multiplex (M/PCRTeq-Bc) para diagnóstico T. equi e Babesia caballi foram avaliadas comparativamente a nested PCR (N/PCR-Teq) no diagnóstico de piroplasmose equina. Na determinação da sensibilidade com DNA em diluições múltiplas de sangue de equino positivo para T. equi, as PCR-Teq e $N$ / PCR-Teq detectaram DNA do hemoparasito nas diluições maiores (1:128), mas não diferiu significativamente da $M$ / PCRTeq-Bc (1:64). Na análise com soros de equinos testados por ELISA houve uma concordância elevada entre esse teste sorológico e a PCR-Teq $(k=0,780)$ e moderada com $N /$ PCRTeq $(k=0.562)$ e M/PCRTeq-Bc $(k=0.488)$. A PCR-Teq determinou freqüência maior de T. equi tanto nos equinos de criação extensiva como na intensiva, entretanto essa não foi signi-

\footnotetext{
${ }^{1}$ Received on January 21, 2011.

Accepted for publication on March 5, 2011.

${ }^{2}$ Escola de Medicina Veterinária, Universidade Federal da Bahia (UFBA), Av. Adhemar de Barros 500, Ondina, Salvador, BA 40110-170, Brazil. *Corresponding author: franke@ufba.br
}

ficativa com relação N/PCR-Teq ( $\mathrm{P}>0.05)$, e ambas PCRs indicaram que há uma situação endêmica para T. equi na população de equinos que constaram da amostragem. A PCR-Teq diferiu significativamente apenas para a $\mathrm{M} / \mathrm{PCRTeq}-\mathrm{Bc}(\mathrm{P}<0.05)$. A PCR-Teq apresentou alta sensibilidade e especificidade comparável a $N$ /PCR-Teq, mas com a vantagem de maior rapidez na obtenção dos resultados e menor custo e risco de contaminação no laboratório. Isso credencia a PCR-Teq para estudos epidemiológicos e para determinação de equinos portadores.

TERMOS DE INDEXAÇÃO: Theileria equi, PCR, multiplex PCR, equinos.

\section{INTRODUCTION}

Equine piroplasmosis is caused by the protozoa Babesia caballi and Theileria equi. The geographical distribution of these protozoa is directly related to the presence of vector ticks, among which the genera Anocentor, Hyalomma and Rhipicephalus (especially the subgenus Boophilus) stand out. These are found in tropical and subtropical zones (Uilenberg 2006). Equine piroplasmosis causes losses through morbidity, mortality, treatment expenditure and restriction of international trade, because of the risk of introducing 
Theileria equi into unaffected or partly free regions (Uilenberg 2006). In the acute phase of T. equi infection, the clinical diagnosis is not conclusive, and therefore parasitological examinations are used, because of their high specificity and sensitivity during this phase of infection. In the chronic phase, parasitological diagnoses present low sensitivity and their use in epidemiological studies or for determinations on affected animals is not recommended.

The World organization for animal Health (OIE) uses the competitive enzyme immunoadsorption test (ELISAc) for certification of horses for exportation (Nantes \& Zappa, 2008). This test presents high sensitivity in comparison with the complement fixation test that was previously indicated. Because of the possibility of cross-reactions (Baldani et al. 2008) and false negative reactions in ELISAc, a combination of these reactions with a direct diagnosis technique will provide greater security in detecting infected animals. In vitro cultivation is a sensitive and specific technique for identifying T. equi, but it is expensive and occurs slowly in comparison with molecular techniques.

Various types of PCR have been developed for diagnosing T. equi and B. caballi (Nicolaiewsky et al. 2001, Rampersad et al. 2003, Alhassan et al. 2005, Heim et al. 2007). PCRs in conventional and multiplex format have the advantage of speed of diagnosis in relation to nested PCR, but the latter is considered more sensitive, even though there is a greater likelihood of sample contamination (Baldani et al. 2008). The present study evaluated the sensitivity, specificity and performance of PCRs based on the sequence of the gene 18S rRNA of T. equi in standard and multiplex formats, in relation to nested PCR, in epidemiological studies.

\section{MATERIALS AND METHODS}

\section{Sample collection and DNA extraction}

Equine blood samples were collected by puncturing capillary vessels of the pinna and were put into vials containing ETDA and kept refrigerated for transportation to the Veterinary Infectology Laboratory of the Federal University of Bahia where they were kept at $-20^{\circ} \mathrm{C}$ until use.

DNA extraction on the blood samples was accomplished using a commercial kit (Purelink ${ }^{\mathrm{TM}}$ Genomic DNA MiniKit; Invitrogen) in accordance with the manufacturer's instructions. The purified DNA was eluted in a volume of $100 \mu \mathrm{l}$ of TE buffer and kept at $-20^{\circ} \mathrm{C}$.

\section{Molecular techniques}

For multiplex PCR (M/PCRTeq-Bc), primers designed based on the sequences of the gene 18SrRNA of Theileria equi (Teq) and Babesia caballi $(\mathrm{Bc})$ were used. The T. equi sequences were TeqF forward 5'-ATGCCCTTCAGTTCG- 3' and TeqR reverse 5'-ACCTCCC TGTGTCAGGATTG- 3'. The B. caballi sequences were BcF forward 5'-GAGGGACTTTGGGTCATAA-3' and BcR reverse q5'-GGTACTCG ATCGGTAGGA-3'. These reactions were accomplished in volumes of $50 \mu \mathrm{L}$ with $2 \mathrm{mM}$ of $\mathrm{MgCl}_{2}, 0.2 \mathrm{mM}$ of dNTPs, $1.5 \mathrm{U}$ of Taq platinum polymerase (Invitrogen), BSA $(10 \mathrm{mg} / \mathrm{ml}), 1 \mathrm{pmol}$ of each of the TeqF and TeqR primers, 20 pmol of each BcF and BcR, and $1 \mu \mathrm{l}$ of genomic DNA. The reaction was carried out as $94^{\circ} \mathrm{C}$ for 2 minutes, followed by 40 cycles of $94^{\circ} \mathrm{C}$ for 1 minute, $58^{\circ} \mathrm{C}$ for 1 minute and $72^{\circ} \mathrm{C}$ for 1 minute, with a final extension of $72^{\circ} \mathrm{C}$ for 5 minutes.

The standard PCR for T. equi (PCRTeq) was performed with the Teq primers that were used in the multiplex PCR, in a volume of $50 \mu \mathrm{L}$ with $2 \mathrm{mM}$ de $\mathrm{MgCl}_{2}, 0.2 \mathrm{mM}$ of dNTPs, $2.5 \mathrm{pmol}$ of each of the TeqF and TeqR primers, $2 \mathrm{U}$ of Taq platinum polymerase and 1 $\mu \mathrm{L}$ of genomic DNA. The thermocycling consisted of $94^{\circ} \mathrm{C}$ for 2 minutes, followed by 35 cycles of $94^{\circ} \mathrm{C}$ for 30 seconds, $60^{\circ} \mathrm{C}$ for 30 seconds and $72^{\circ} \mathrm{C}$ for 30 seconds, with a final extension of $72^{\circ} \mathrm{C}$ for 5 minutes. The nested PCR for detection of $T$. equi (N/PCRTeq) was performed in accordance with the technique described by Nicolaiewsky et al. (2001).

The products from the three PCRs were stained with Sybr Gold (Invitrogen) solution and subjected to a horizontal electrophoresis run on 1.5\% agarose gel, in Tris-borate EDTA (TBE) buffer, together with the $100 \mathrm{bp}$ molecular weight marker (Invitrogen). The results were viewed in a transilluminator and were documented by photographing them (Biometra).

The T. equi and B. caballi amplicons were purified from the agarose gel using a commercial kit (PureLink ${ }^{\mathrm{TM}}$ Quick Gel Extraction Kit; Invitrogen), and were cloned and sequenced in a capillary automated sequencer (ABI 3100; Applied Biosystems). The clone sequences of the final portion of the genes of T. equi and B. caballi were compared with the sequences of the gene 18SrRNA of these microorganisms that are filed in GenBank, using the BLASTX algorithm, from the NCBI website (http://www.ncbi.nlm.nih.gov). The clone sequences of T. equi were also compared with each of these separately, using the MEGALIGN software (Lasergene/ DNASTAR Inc.).

\section{Sensitivity and specificity analysis}

The specificities and sensitivities of PCR-Teq, $M /$ PCRTeq-Bc and $N /$ PCR-Teq were analyzed using DNA extracted from red blood cell concentrates obtained from 49 horses that had been reared in stables in the municipality of Bagé, Rio Grande do Sul. These horses were serologically either negative or positive in the ELISA test with recombinant antigen EMA-1 that had been developed in the Federal University of Pelotas by Dr. Sergio da Silva (personal information). The relationship between the results from the ELISA test and from the PCRs was determined using the kappa test.

Additionally, to evaluate the sensitivity of the three PCRs, the equine DNA that had been proven positive for T. equi, with a concentration of $0.328 \mu \mathrm{g} / \mathrm{ml}$ that had been determined using fluorometry (Qubit@ - Invitrogen), was multiply diluted from 1:2 to 1:512.

\section{Epidemiological study}

Blood samples from 118 horses in the state of Bahia were used to evaluate the performance of the three molecular tests in epidemiological studies. Among these 118 horses, 62 were reared in an intensive system, with the transmitter tick under control, came from breeding stables owned by the military police. The remaining 56 horses came from commercial farms, without tick control (extensive rearing system). In this evaluation, the PCR results were analyzed using the Kruskal-Wallis test. For classification purposes, ticks were gathered from all the 15 horses that presented infestation at the time of drawing blood.

\section{RESULTS AND DISCUSSION}

The PCRTeq and $M$ /PCRTeq-Bc reactions produced amplicons of $283 \mathrm{bp}$ (Fig.1), and sequencing of the products from these reactions found $100 \%$ identity with the corresponding sequences of Theileria equi (AY50063.2; EU 888902.1; EU888906.1) that exist in GenBank.

The relative sensitivity results from PCRTeq, $M /$ PCRTeqBc and N/PCRTeq, with multiple DNA dilutions on horses that were positive for T. equi, are shown in Table 1. PCRTeq and $N$ / PCRTeq presented identical sensitivity that was greater (1:128) than for $M /$ PCRTeq-Bc (1:64), thus demonstrating that PCRTeq has high efficiency in relation to other conventional 


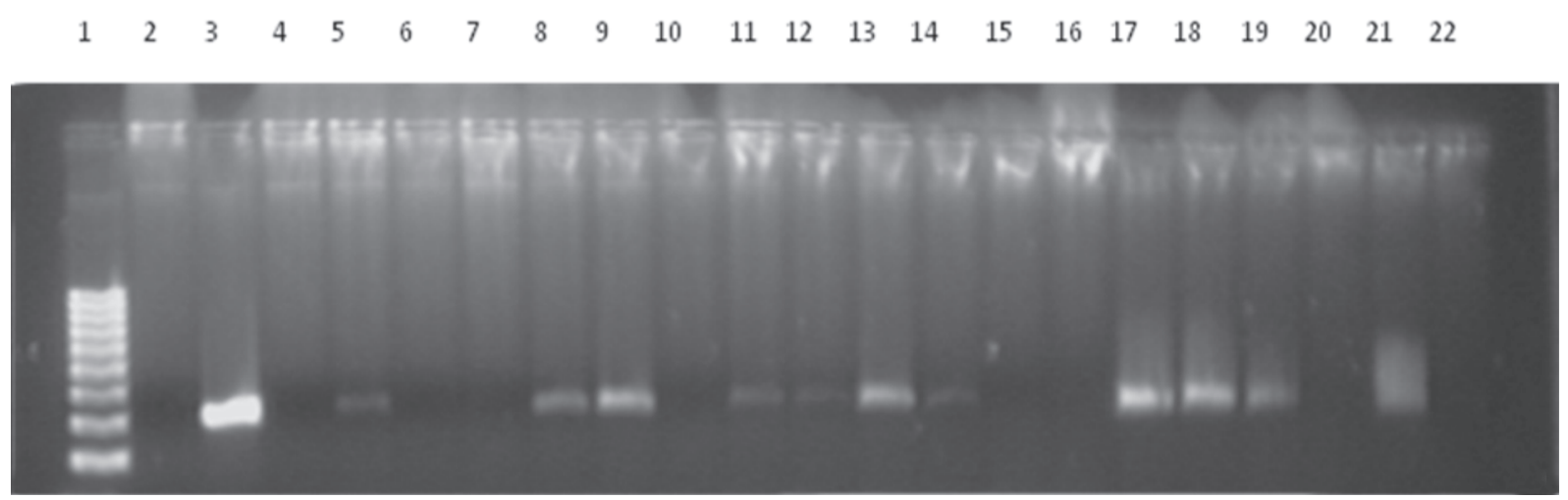

Fig.1. 1.5\% agarose gel from PCR for T. equi (PCR-Teq) on epidemiological study samples. 1. 100 bp marker; 2 . Negative control; 3. Positive control; 4, 6, 7, 10, 15, 16, 20 and 22. Negative samples; 5, 8, 9, 11, 12, 13, 14, 17, 18,19 and 21. Positive samples.

Table 1. Sensitivity of conventional PCR (PCRTeq), multiplex PCR (M/PCRTeq-Bc) and nested PCR (N/PCRTeq) for diagnosing of Theileria equi, determined by means of multiple DNA dilutions on equine samples with proven infection by this hemoparasite

\begin{tabular}{cccc}
\hline \multicolumn{4}{c}{ Types of PCR } \\
\hline DNA dilutions & PCRTeq & $M /$ PCRTeq-Bc & $N /$ PCRTeq \\
\hline $1: 2$ & + & + & + \\
$1: 4$ & + & + & + \\
$1: 8$ & + & + & + \\
$1: 16$ & + & + & + \\
$1: 32$ & + & + & + \\
$1: 64$ & + & + & + \\
$1: 128$ & + & - & + \\
$1: 256$ & - & - & - \\
$1: 512$ & - & - & -
\end{tabular}

PCR protocols described in the literature. These other PCR protocols present sensitivity that is about half that of nested PCR, as seen in diagnosing other hemoparasites (Aboulaila et al. 2009) and T. equi (Rampersad et al. 2003). From the results presented by Baldani et al. (2008), it is evident that nested PCR has higher sensitivity: in their study, nested PCR identified $100 \%$ of the horses affected by T. equi, while conventional PCR on the same samples only presented negative results. The greater capacity of nested PCR for identifying naturally infected horses is due to the fact that this technique detects smallersized parasitemia $\left(6 \times 10^{-6} \%\right.$ to $\left.8 \times 10^{-6} \%\right)$ than does conventional PCR (only down to $8 \times 10^{-5} \%$ ) (Bashiruddin et al. 1999, Nicolaiwsky et al. 2001, Baldani et al. 2008). So far, only real-time PCR has been described as having sensitivity greater than or equal to nested PCR (Kim et al. 2007).

From analysis of the PCRTeq, M/PCRTeq-Bc and N/ PCRTeq results in relation to the findings from the ELISA test, it was found that there was substantial agreement between
ELISA and PCRTeq, while N/PCRTeq and M/PCR-Teq presented moderate agreement with ELISA (Table 2). This suggests that PCRTeq has a high capacity to detect affected individuals. Because of the high sensitivity, the agreement between this type of PCR and ELISA could even be bigger, considering that there may be false positive results, due to persistency of antibodies in horses that are no longer affected. In a study in Mongolia, Rüegg et al. (2007) examined 510 horses using indirect immunofluorescence (IFI) techniques and PCR for T. equi, and obtained positive results in $78.8 \%$ and $66.5 \%$ respectively. Jaffer et al. (2009) also found that larger number of horses reacted to the serological test (36.2\%) than to PCR (31.4\%).

The three PCRs presented possible false positive reactions in relation to the ELISA results, and these occurrences did not differ significantly between the three tests (Table 2). Considering that the seronegative results can be attributed to failure of the test to detect recent infection when the level of antibodies is still low (Nantes \& Zappa 2008), it is possible that the results obtained from the PCRs are actually positive. This would be a factor favoring PCR for diagnosing T. equi infection early on.

The specificity of the PCRs for T. equi used in this study was evaluated using two equine samples that were parasitologically positive for B. caballi, and both of them presented a negative result (data not shown).

PCRTeq was capable of identifying a larger number of horses reared in both extensive and intensive systems that tested positive for T. equi, although this difference was only significant in relation to M/PCRTeq-Bc (Table 3). These results corroborate previous comparative evaluations of sensitivity and specificity, in which PCRTeq showed identical performance to $N$ /PCRTeq in the statistical analysis.

With regard to husbandry type among the horses examined, all three PCRs detected a larger number of positive

Table 2. Number and percentage of positive and negative reactions in conventional PCR (PCRTeq), multiplex PCR (M/PCRTeq-Bc) and nested PCR (N/PCRTeq) for diagnosing Theileria equi in DNA extracted from serologically positive equine blood that had been tested by means of ELISA

\begin{tabular}{|c|c|c|c|c|c|c|}
\hline \multirow[t]{2}{*}{ ELISA } & \multicolumn{2}{|c|}{ PCRTeq (a) } & \multicolumn{2}{|c|}{$M /$ PCRTeq-Bc $^{(\mathrm{b})}$} & \multicolumn{2}{|c|}{$N /$ PCRTeq ${ }^{(\mathrm{c})}$} \\
\hline & Positive & Negative & Positive & Negative & Positive & Negative \\
\hline Positive & $16(84.2 \%)$ & $3(15.8 \%)$ & $8(42.1 \%)$ & $11(57.9 \%)$ & $12(62.3 \%)$ & 7 (36.8\%) \\
\hline Negative & $2(6.7 \%)$ & $28(93.3 \%)$ & $1(3.3 \%)$ & $29(96.7 \%)$ & $3(10.0 \%)$ & $27(90.0 \%)$ \\
\hline
\end{tabular}

(a) $k=0.784$; $^{\text {(b) }} k=0.488$; (c) $k=0.562$. 
Table 3. Results from conventional PCR (PCRTeq), multiplex PCR (M/PCRTeq-Bc) and nested PCR ( $N$ /PCRTeq) for diagnosing Theileria equi in horses in extensive and intensive rearing systems in the state of Bahia

\begin{tabular}{cccc}
\hline Rearing system & PCRTeq & $M /$ PCRTeq-Bc & $N /$ PCRTeq \\
\hline Extensive & $* 84.6 \%(44 / 52)$ & $* 67.3 \%(35 / 52)$ & $82.7 \%(43 / 52)$ \\
Intensive & $* 51.6 \%(32 / 62)$ & $* 29.1 \%(18 / 62)$ & $43.6 \%(27 / 62)$
\end{tabular}

* PCRTeq - M/PCRTeq-Bc $(\mathrm{p}<0.05) ; \quad$ PCRTeq - N/PCRTeq (p>0.05); $N /$ PCRTeq - $M$ /PCRTeq $(\mathrm{p}>0.05)$.

animals in the extensive system than in the intensive system. Only the latter rearing system includes tick control (Table 3). A similar result was described previously by Botteon et al. (2002), in a comparative study using the IFI technique that investigated the frequency of infection by T. equi among 121 horses that were subjected to different rearing systems. In that study, the authors registered positive results in $89.58 \%$ of the animals in an extensive system; $87.89 \%$ in a semiconfined system and only $45.24 \%$ in a confined system. These results reflect the lowest rate of inoculation of this hemoparasite in animals reared in an intensive system, due to the lower infestation of vector ticks.

The tick sample from the infested horses that were evaluated in this study identified 14 specimens of the genus Anocentor and only one of Amblyomma cajannense. Predominance of the genus Anocentor and high frequency of T. equi were also reported in the state of Rio de Janeiro (Pereira et al. 2004, Costa-Pereira et al. 2005, 2007), although some authors believe that these ticks are not capable of transmitting T. equi (Stiller \& Coan 1995). The main vector for this hemoparasite in Brazil is the Rhipicephalus B. microplus (Heuchert et al. 1999, Battsetseg et al. 2002a), especially in cases of pasture sharing with cattle (Ribeiro et al. 1999, Labruna et al. 2001).

Comparisons between epidemiological situations of endemism present a certain degree of subjectivity, due to various factors that affect $T$. equi transmission, such as the animal management system; tick species and populations; and climatic conditions and seasonal variations. The results from the epidemiological evaluation, using PCRTeq, $N$ /PCRTeq and M/PCRTeq-Bc (Table 3), characterize an endemic situation comparable to what was observed in surveys on horses in Minas Gerais, Goiás, São Paulo and Mato Grosso do Sul, using PCR techniques (Heim et al. 2007, Kim et al. 2007). In other countries in which $T$. equi is endemic, frequencies similar to those observed in this study have been found, also using PCR (Rüegg et al. 2007, Jaffer et al. 2009). Based on the presented data, we conclude that PCRTeq, which is similar to N/PCRTeq, presents high sensitivity and specificity, which makes it appropriate for epidemiological studies and detection of affected individuals, and it also presents advantages in terms of speed of execution, lower cost and reduced risk of contamination.

Acknowledgements.- To the Research Support Foundation of the State of Bahia (Fapesb) for financial support through Research Project Support Announcement no.005/2007; to the Coordination Office for Advancement of University-level Personnel (CAPES), for the master's degree bursary that was granted; and to the researchers Dr. Sérgio da Silva of the Federal University of Pelotas and Dr. Carlos Massard of the Federal Rural University of Rio de Janeiro for the donation of equine samples.

\section{REFERENCES}

Aboulaila M., Yokoyama N. \& Igarashi I. 2009. Development and evaluation of a nested PCR based on spherical body protein 2 gene for the diagnosis of Babesia bovis infection. Vet. Parasitol. D oi:10.1016/j.vetpar. 2009.12.013.

Alhassan A., Pumidonming W., Okamura M., Hirata H., Battsetseg B., Fujisaki K., Yokoyama N. \& Igarashi I. 2005. Development of a single round and multiplex PCR method for the simultaneous detection of Babesia caballi and Babesia equi in horse blood. Vet. Parasitol. 129:43-49.

Baldani C.D., Canola P. A., Neto J. C. L. \& Machado R.Z. 2008. In vitro culture, PCR, and nested PCR for the detection of Theileria equi in horses submitted to exercise. Arq. Bras. Med. Vet. Zootec. 60(3):550-558.

Bashiruddin J.B., Cammà C. \& Rebêlo E. 1999. Molecular detection of Babesia equi and Babesia caballi in horse blood by PCR amplification of part of the $16 \mathrm{~S}$ rRNA gene. Vet. Parasitol. 84:75-83.

Battsetseg B., Lucero S., Xuan X., Claveria F.G., Inoue N., Alhassan A., Kanno T., Igarashi I., Nagasawa H., Mikami T. \& Fujisaki K. 2002. Detection of natural infection of Boophilus microplus with Babesia equi and Babesia caballi in Brazilian horses using nested polymerase chain reaction. Vet. Parasitol. 107:351-357.

Botteon P.T.L., Massard C.L., Botteon R.C.C.M., Loss Z.G. \& Linhares G.F.C. 2002. Seroprevalencia de Babesia equi en três diferentes sistemas de crianza de equinos. Rio de Janeiro, Brasil. Parasitol. Latinoamericana 57:141-145.

Costa Pereira M.A.V., Massard C.L., Faccini J.L.H. \& Siqueira L.F.G. 2005. Variação da sorotitulação ao teste de fixação de complemento para Babesia equi e Babesia caballi em equinos da região serrana do Rio de Janeiro. Ars Vet. 21(3):338-343.

Costa Pereira M.A.V., Massard C.L. \& Vita G.F. 2007. Babesiose eqüina: Enzootia em Nova Friburgo, Rio de Janeiro, Brasil. Revta Port. Ciênc. Vet. 102(561/562):165-167.

Heim A., Passos L.M.F., Ribeiro M.F.B., Costa-Junior L.M., Bastos C.V., Cabral D.D., Hirzmann J. \& Pfister K. 2007. Detection and molecular characterization of Babesia caballi and Theileria equi isolates from endemic areas of Brazil. Parasitol. Res. 102:63-68.

Heuchert C.M.S., Giulli Jr V., Athaide D.F. \& Fieldhoff K.T. 1999. Seroepidemiologic studies on Babesia equi and Babesia caballi infections in Brazil. Vet. Parasitol. 85:1-11.

Jaffer O., Abdishakur F., Hakimuddin F., Riya A., Wernery U. \& Schuster R.K. 2009. A comparative study of serological tests and PCR for the diagnosis of equine piroplasmosis. Parasitol. Res. Doi 10.1007/s00436-009-1669-5.

Kim J.Y., Cho S.H., Joo H.N., Tsuji M., Cho S.R., Park I.J., Chung G.T., Ju J.W., Cheun H.I., Lee H.W., Lee Y.H. \& Kim T.S. 2007. First case of human babesiosis in Korea: Detection and characterization of a novel type of Babesia sp. (KO1) similar to ovine Babesia, J. Clin. Microbiol 45:2084-2087.

Labruna M.B., Kerber C.E., Ferreira F., Faccini J.L.H., De Waal D.T. \& Gennari S.M. 2001. Risk factors to tick infestations and their ocurrence on horses in the state of São Paulo, Brazil. Vet. Parasitol. 97:1-14.

Nantes J.H. \& Zappa V. 2008. Nutaliose: revisão de literatura. Revta Cient. Eletrôn. Med. Vet. ISSN: 1679-7353, n.10, 2008.

Nicolaiewsky T.B., Richter M.F., Lunge V.R., Cunha C.W., Delagostin O., Ikuta N., Fonseca A.S., Silva S.S. \& Ozaki L.S. 2001. Detection of Babesia equi (Laveran, 1901) by nested polymerase chain reaction. Vet. Parasitol. 101:9-21.

Pereira M.A.V., Massard C.L., Faccini J.L.H \& Siqueira L.F.G. 2004. Ocorrência de Babesia equi (Laveran, 1901) e Babesia caballi (Nutall \& Strickland, 1912) em equinos de raça puro sangue inglês de pequenos estabelecimentos equëstres. Arqs Inst. Biológico, São Paulo, 71(4):405-409.

Rampersad J., Cesar E., Campbell M.D., Samlal M. \& Ammons D. 2003. A field evaluation of PCR for the routine detection of Babesia equi in horses. Vet. Parasitol. 114,:81-87.

Ribeiro M.F., Costa J.O. \& Guimarães A.M. 1999. Epidemiological aspects of Babesia equi in horses in Minas Gerais, Brazil. Vet. Res. Commun. 23(6):385-390.

Rüegg S.R., Torgerson P., Deplazes P. \& Mathis A. 2007. Age-dependent dynamics of Theileria equi and Babesia caballi infections in southwest Mongolia based on IFAT and/or PCR prevalence data from domestic horses and ticks. Parasitology 134:939-947.

Stiller D. \& Coan M.E. 1995. Recent developments in elucidating tick vector relationships for anaplasmosis and equine piroplasmosis. Vet. Parasitol. 57:97-108.

Uilenberg G. 2006. Babesia: A historical overview. Vet. Parasitol 138(1/2):3-10. 